\title{
PESAN DARI SLEBOR: ANALISIS WACANA KRITIS TERHADAP FENOMENA BAHASA TULIS STIKER SEPEDA MOTOR
}

\author{
Slamet Setiawan, Yustus Sentus Halum \\ Universitas Negeri Surabaya, slametsetiawan@unesa.ac.id \\ STKIP Santu Paulus Ruteng
}

\begin{abstract}
One of the interesting phenomena in the use of written language is found in motor cycle stickers. The use of language is able to reveal social dimension and show social culture of a given society. This study focuses on messages in the motorcycle stickers: 1) describing patterns of language structures and other linguistic elements; 2) describing relationship patterns among participants; and 3) unsealing what and how socio-cultural phenomena. Theoretical Framework in this study refers to what is stated by Fairclough (1995): Critical Discourse Analysis (CDA). CDA is discourse analysis which involves sociocultural phenomena expressed through the use of language. Based on 70 motor cycle stickers; using descriptive qualitative method; and applying Fairclough theory, it is found that: 1) Language patterns used in the stickers are casual type which employ short and incomplete structures. 2) There are three strong relationship patterns among participants: motorcycle rider, social class, and gender. 3) There are three main reflections drawn from social phenomena: social classes; Secondly, socio-politic policy applied for gender equality; phenomena of how bahasa gaul influences the use of proper and correct Bahasa Indonesia.
\end{abstract}

Key Words: CDA (Critical Discourse Analysis), mudguard, micro-meso-macro interpretation

\section{PENDAHULUAN}

WARNING! Hari gini gak ada gigi, udah kaya engkong gue. Interpretasi bisa beragam bergantung seberapa luas pengetahuan pembaca terhadap bahasa dan konteks sosial yang melekat pada bahasa. Meskipun demikian, tidak dapat dihindari bahwa keseluruhan penafsiran akan mengacu pada salah satu fenomena bahasa dalam kultur sosial tulisan stiker sepeda motor.

Halliday (1978:10) percaya bahwa bahasa memiliki dimensi semiotika sosial, yakni bahasa adalah sistem tanda yang dikembangkan untuk mengekspresikan makna sosial. Bahasa mengisyaratkan fungsi menyediakan sarana bagi orang untuk bertindak dan memegang kendali atas lingkungan mereka dengan proses apa yang disebut proyeksi konseptual, yang disebut Halliday (1994:436) sebagai fungsi ideasional bahasa. Fungsi lain dari bahasa, menurut Halliday (1994:436) adalah penyediaaan sarana bagi orang 
untuk berinteraksi satu sama lain dalam rangka membangun kerja sama dan relasi sosial. Jadi bahasa juga memiliki fungsi interpersonal. Selain itu, bahasa berperan menghubungkan teks dan konteks yang memiliki fitur fonologis dan tematik tertentu. Ini berarti bahwa bahasa juga memiliki fungsi tekstual.

Fungsi ideasional, interpersonal, dan tekstual ditafsirkan sebagai komponen fungsional dari sistem semantik. Mereka hadir dalam setiap penggunaan bahasa dalam setiap konteks sosial. Sebuah teks merupakan produk ketiga fungsi tersebut. Tiga metafungsi bahasa itu terkait erat dengan konteks dan diwujudkan dalam lexicogramatikal bahasa.

Definisi wacana yang dikemukakan saling melengkapi satu dengan lainnya. Fairclough (1995:28-32) dan Wodak (2001:5) mengatakan bahwa wacana adalah pemakaian bahasa yang tampak praktik sosial; sedangkan analisis wacana adalah mengenai bagaimana teks bekerja/berfungsi dalam praktik sosial-budaya. Bentuk analisis wacana yang melibatkan fenomena sosial dalam pemakaian bahasa ini dikenal dengan sebutan analisis wacana kritis (critical discourse analysis). Dalam hal ini, Fairclough memandang wacana sebagai interaksi sosial yang terungkap melalui pemakaian bahasa. Aspek-aspek yang dikaji meliputi bentuk, struktur, dan organisasi teks mulai dari tataran yang terendah fonologi (fonem), gramatika (morfem, kata, frase, klausa, dan kalimat), leksikon (kosakata), sampai dengan tataran yang lebih tinggi seperti sistem pergantian percakapan, struktur argumentasi, dan jenis-jenis aktivitas.

Brown dan Yule (1983:1-2) berpendapat, analisis wacana adalah analisis atas bahasa yang digunakan. Analisis wacana mengkaji tujuan bahasa digunakan. Di dalam analisisnya kedua ahli tersebut memfokuskan pada dua fungsi utama : (1) fungsi transaksional, yaitu fungsi bahasa unttuk mengungkapkan isi, dan (2) fungsi interaksional, yaitu fungsi bahasa yang terlibat dalam pengungkapan sikap individu dan interaksi sosial.

Meskipun terdapat sedikit gradasi antara definisi di atas, titik temunya adalah analisis wacana berhubungan dengan studi mengenai bahasa atau pemakaian bahasa. Dalam analisis wacana kritis (CRITICAL Discourse AnAlysis / CDA), wacana tidak hanya dipahami sebagai studi bahasa. Bahasa dianalisis tidak hanya dengan menggambarkan aspek kebahasaan, tetapi juga dengan menghubungkannya dengan KONTEKS. Konteks berarti bahasa dipakai untuk tujuan dan praktik tertentu. 
Ruth Wodak juga telah membuat kontribusi yang luar biasa untuk bidang studi ini. Fairclough (1995:57-62) mengembangkan kerangka tiga dimensi untuk mempelajari wacana, yakni dimensi analisis teks (lisan atau tulisan), dimensi analisis praktik wacana (proses produksi teks, distribusi dan penggunaannya), dan dimensi analisis peristiwa diskursif sebagai contoh praktik sosiokultural. Secara khusus, ia memetakan ketiga dimensi tersebut ke dalam level interpretasi level mikro, meso, dan makro. Pada tingkat mikro, analis terfokus pada tataran sintaksis teks, struktur metaforis, dan perangkat retoris tertentu. Pada level meso, yang terlibat adalah produksi teks (siapa, kapan, di mana) dan penggunaannnya, berfokus pada bagaimana hubungan kekuasaan yang berlaku dalam teks. Pada tingkat makro, analisis dikaitkan dengan pemahaman intertekstual, yakni mencoba menghubungkan fenomena sosial yang mempengaruhi teks yang sedang dipelajari. Paradigma inilah yang akan dipakai sebagai landasan teori pada kajian ini utuk menganalisis ragam bahasa tulis pada stiker yang dipasang di slebor sepeda motor.

Diyakini bahwa penelitian ragam bahasa tulis pada stiker sepeda motor telah dilakukan Surana (2003). Penelitian ini hanya fokus pada proses pembentukan wacana stiker humor; tidak dikaitkan dengan Analisis Wacana Kritis (AWK=CDA). Namun penelitian ini mendasarkan seluruh kajiannya pada teori AWK dengan pertimbangan bahwa wacana pada stiker sepeda motor dibuat dan ditempelkan dengan alasan dan maksud tertentu. Gaya bahasa yang dipamerkan juga pasti memiliki latar belakang sosial budaya tertentu.

Terkait dengan hal di atas, penelitian ini dilakukan untuk mengkaji: (1) pola tata bahasa dan unsur linguistik lain yang disampaikan lewat tulisan stiker sepeda motor ditinjau dari sudut pandang mikro CDA; (2) pola hubungan antar partisipan yang terjalin melalui ungkapan stiker sepeda motor ditinjau dari sudut pandang meso CDA; (3) fenomena sosial budaya tergambar pada stiker sepeda motor ditinjau dari sudut pandang makro CDA.

\section{Kerangka Teori}

Dalam studi analisis wacana (discourse analysis), pengungkapan seperti itu termasuk dalam kategori analisis wacana kritis (critical discourse analysis-CDA). Bahasa dalam analisis wacana kritis adalah bahasa digunakan sebagai media yang dipakai untuk tujuan dan praktik tertentu termasuk praktik ideologi dan pencetusan situasi sosial budaya yang melingkupi wacana.

174 | E-ISSN: 2527-8754 http:// journal.unesa.ac.id/index.php/Paramasastra 
Banyak kajian ilmiah bahasa yang telah didedikasikan untuk analisis wacana tradisional, yang berfokus pada data lisan dan tulisan (Brown dan Yule, 1983; Cook, 1994; Coulthard, 1985; 1994; Dijk, 1985; Georgakopoulou dan Goutsos, 1997; Halliday, 1989; Nunan, 1993; Schiffrin, 1994; Tannen, 1993). Kerangka analisis penelitian ini sebagian besar didasarkan pada ide Fairclough (1989; 1992; 1995; 2001; 2003). Fairclough berpendapat bahwa analisis wacana kritis adalah mengacu kepada penggunaan bahasa yang menyebabkan kelompok sosial "bertarung" dan mengajukan ideologinya masing-masing. Konsep ini berasumsi bahwa wacana dapat saja memproduksi hubungan kekuasaan yang tidak imbang antara kelas sosial, laki-laki dan wanita, kelompok mayoritas dan minoritas yang perbedaan itu direpresentasikan dalam praktik sosial. Analisis Wacana melihat pemakaian bahasa tutur dan tulisan sebagai praktik sosial.

Dalam hal ini, penjelasan Norman Fairclough mengindikasikan bahwa dalam analisis wacana, seorang peneliti atau penulis melihat teks sebagai hal yang memiliki konteks baik berdasarkan "process of production" atau "text production"; "process of interpretation" atau "text consumption" maupun berdasarkan praktik sosio-kultural. Dengan demikian, untuk memahami wacana (naskah/teks) tidak dapat melepaskan dari konteksnya. Untuk menemukan "realitas" di balik teks diperlukan penelusuran atas konteks produksi teks, konsumsi teks, dan aspek sosial budaya yang mempengaruhi pembuatan teks.

Gagasan tentang Wacana dalam CDA

CDA melihat bahasa sebagai 'praktik sosial' (Fairclough dan Wodak, 1997:258), dan menganggap "konteks penggunaan bahasa" sebagai bagian yang penting. Berikut adalah salah satu gagasan tentang CDA yang 'sangat populer' di kalangan peneliti CDA:

CDA sees discourse - language use in speech and writing - as a form of 'social practice'. Describing discourse as social practice implies a dialectical relationship between a particular discursive event and the situation(s), institution(s) and social structure(s), which frame it: The discursive event is shaped by them, but it also shapes them.That is, discourse is socially constitutive as well as socially conditioned - it constitutes situations, objects of knowledge, and the social identities of and relationships between people and groups of people. It is constitutive both in the sense that 
it helps to sustain and reproduce the social status quo, and in the sense that it contributes to transforming it. Since discourse is so socially consequential, it gives rise to important issues of power. Discursive practices may have major ideological effects - that is, they can help produce and reproduce unequal power relations between (for instance) social classes, women and men, and ethnic/cultural majorities and minorities through the ways in which they represent things and position people. (Fairclough and Wodak, 1997: 258)

Perspektif penting lain dalam CDA terkait dengan konsep 'kekuatan' yang dinegosiasikan ke dalam wacana. Dalam teks, perbedaan diskursif diatur oleh perbedaan kekuatan yang ada di bagian decode, serta ditentukan oleh wacana dan oleh genre. Secara singkat, CDA dapat didefinisikan sebagai dasar analisis hubungan struktural, dominasi, diskriminasi, kekuasaan dan kontrol seperti yang dituturkan dalam bahasa. Dengan kata lain, CDA bertujuan untuk menyelidiki kesenjangan kritis sosial seperti yang diungkapkan, dibentuk, dilegitimasi, dengan menggunakan bahasa.

\section{CDA dari Sudut Pandang Norman Fairclough}

Karya N. Fairclough pada tahun 1989 berfokus pada layar kekuasaan yang ditampilkan bahasa (Fairclough, 1989). Daya tersebut meliputi kekuatan politik dan status sosial. Fairclough berfokus pada sebagian besar data percakapan, yakni informasi tekstual, misalnya, propaganda politik. Dalam edisi terbaru, Fairclough telah menambahkan ide-idenya tentang penggunaan bahasa modern dan tampilan kekuasaan pada tingkat yang baru: website (Fairclough, 2001), tetapi bagian ini idak relevan dengan penelitian pada wacana stiker sepeda motor ini.

Fairclough (2001: 64) percaya bahwa untuk menganalisis bahasa dan perebutan kekuasaan yang termaktub di dalamnya, teks itu sendiri pertama harus hati-hati dipertimbangkan; maka faktor-faktor sosial yang mempengaruhi bagaimana teks ditulis harus diperhitungkan.

Rose (2001) membahas pendekatan yang sama untuk analisis tekstual dan informasi visual. Dia mengusulkan dua tipe analisis wacana. Tipe I adalah analisis 176 | E-ISSN: 2527-8754 http:// journal.unesa.ac.id/index.php/Paramasastra 
tingkat mikro, dengan fokus pada wacana itu sendiri, sedangkan tipe II adalah analisis meso-level, dengan fokus yang terletak pada "ptactices of institution" (Rose, 2001: 140). Fairclough menggambarkan analisis tingkat mikro sebagai "deskripsi" dari teks (Fairclough, 2001: 91), misalnya, kosakata yang digunakan, sintaks, dan tata bahasa yang merupakan gaya penulisan (Fairclough, 2001: 91 -116). Langkah selanjutnya, analisis tingkat mikro, adalah "interpretasi" (Fairclough, 2001: 118), yang arti dari setiap item leksikal mengarah ke kalimat makna, dan akhirnya ke makna diringkas dari seluruh teks (Fairclough, 2001: 120).

Analisis tingkat mikro berkaitan dengan teks itu sendiri; analisis meso-level adalah tentang faktor sosial dan kelembagaan yang mempengaruhi penciptaan teks; dan analisis tingkat makro berfokus pada ide-ide dan fenomena sosial yang mencerminkan teks.

Untuk melakukan penyandian balik (decoding) makna dari teks keseluruhan, maka pengandaian teks harus dipahami. Penjelasan Fairclough untuk konsep pengandaian adalah bahwa wacana dan teks memiliki sejarah, mereka milik seri sejarah, dan oleh karena itu, interpretasi intertekstual teks dikaitkan dengan unsur kepemilikan bahasa dan kelompok pengguna bahasa yang tergabung di dalamnya (Fairclough, 2001: 127).

Pentingnya konsep pengandaian dan intertekstualitas dicatat dalam sejumlah karya Fairlough (1992, 1995, 2003). Rose (2001: 136-138) juga menekankan pentingnya intertekstualitas dalam teks: tanda-tanda dari satu wacana dapat berhubungan dengan tanda-tanda yang ada pada sumber-sumber lain, misalnya, iklan, berita, sastra atau budaya. Kadang-kadang, tanda-tanda tersebut dapat membuat teks lebih meyakinkan karena memuat ide-ide budaya populer.

Karya Fairlough pada tahun 2003berisi ide-ide dasar dan terminologi analisis linguistik dalam penelitian sosial dan dalam analisis linguistik pada tingkat sosiolinguistik. Hal ini terutama berguna untuk penelitian ini. Banyak istilah tentang wawasan dan instrumen untuk analisis level mikro dan meso yang diberikan dalam tulisan ini. Beberapa istilah teknis yang berhubungan dengan tingkat mikro analisis adalah sebagai berikut (Fairclough , 2003: 91-92 , 98, 115-118 , 135-137 , 145 -146 , 171$173)$. 
1. Tingkat yang lebih tinggi pada hubungan semantik seperti hubungan "problemsolution". Jenis hubungan ini terjadi ketika suatu teks menggambarkan kebutuhan pelanggan, dan menyajikan produk mereka sebagai solusi.

2. Legitimasi, berkaitan dengan rasionalisasi ide penciptaan teks yang mengisyaratkan ide-ide yang menarik misalnya dari bidang hukum, tradisi , moral, atau tren bahasa yang sedang terjadi.

3. Hubungan antara bentuk gramatikal dan fungsi berbicara. Sebagai contoh, teks deklaratif biasanya berisi pernyataan fakta. Teks jenis ini biasanya bersifat meminta konfirmasi; interogatif dan kadang-kadang dapat digunakan sebagai saran atau penawaran; teks imperatif biasanya berisi tuntutan. Hal ini tentu saja tergantung pada konteks, dan penafsir harus berhati-hati saat melakukan analisis.

4. Bentuk eksklusi (apa yang dikecualikan), inklusi (apa yang termasuk) dan informasi dominan (informasi yang paling dominan) dalam teks yang mengungkapkan maksud dari pembuat teks.

5. Bagaimana partisipan dalam teks diwakili. Beberapa contoh adalah: penggunaan inklusi/eksklusi, penggunaan kata ganti/kata benda (misalnya sebagai "dia" atau "seseorang"); penggunaan unsur penamaan/pengklasifikasian ("John", atau "dokter"), serta penggunaan bentuk spesifik/generik (misalnya, "para dokter di ruangan itu" atau dokter pada umumnya).

6. Pernyataan evaluatif yang menggambarkan apakah sesuatu diinginkan atau tidak diinginkan. Misalnya, produk sepeda motor jenis matic yang lebih diinginkan dari pada jenis yang mengunakan perseneling.

Fairclough mengatakan bahwa fenomena linguistik bersifat sosial dalam artian bahwa setiap kali orang berbicara atau mendengarkan atau menulis atau membaca, mereka melakukannya dengan cara yang ditentukan secara sosial dan juga memiliki efek sosial (2001: 19). Pada saat yang sama, fenomena sosiolingustik terjadi karena bahasa yang digunakan dalam konteks sosial tidak hanya merefleksikan atau mengekspresikan kondisi dan praktik sosial semata-mata, tetapi bahasa yang digunakan tersebut adalah bagian dari kondisi sosial itu sendiri (Fairclough, 2001:19). Oleh karena itu, analisis pada level meso dan makro diperlukan sepenuhnya untuk mengartikulasikan makna dalam teks.

Analisis pada level meso atau discource practice memusatkan perhatian pada bidang produksi dan konsumsi teks. Teks terbentuk karena adanya suatu praktik diskursi, 
yang akan menentukan bagaimana teks tersebut dibentuk. Pada analisis level ini, terdapat "kekuatan terselubung" yang bersama teks (Fairclough, 2001: 41). Kekuatan terselubung tersebut menyiratkan sudut pandang tersembunyi produsen (pembuat teks) terhadap suatu topik tertentu yang sedang dibahas, yang kemudian akan mempengaruhi sudut pandang konsumen (khalayak). Dalam tulisan selanjutnya, Fairclough menyebutkan istilah teknis yang berguna untuk analisis pada tingkat meso: "genre mixing" (2003: 34). Sebagai contoh, ketika suatu wacana disajikan dengan petunjuk dari genre brosur wisata, maka campuran genre yang berbeda hadir dalam satu teks. Hal inii menarik bagi kelompok audiens yang berbeda-beda. Fairclough menjelaskan bahwa batas-batas sosial yang kabur dalam kehidupan sosial kontemporer tercermin dalam genre bahasa suatu wacana (Fairclough, 2003: 34).

Analisis makro atau sociocultural practice didasarkan pada asumsi bahwa konteks sosial yang ada diluar teks mempengaruhi bagaimana wacana yang muncul dalam teks. Analisis ini menentukan bagaimana teks diproduksi dan dipahami. Analisis makro menentukan teks secara tidak langsung dan dimediasi oleh praktik kewacanaan. Mediasi tersebut meliputi dua hal, yakni bagaiman teks tersebut diproduksi dan bagaimana teks tersebut diterima dan dikonsumsi.

Jejak Stiker di Indonesia

Tidak banyak buku yang merekam jejak historis stiker di Indonesia. Pada tahun 2008, Ruang Rupa menerbitkan Stiker Kota, yang memuat kajian seluk beluk stiker di Indonesia (Moetidjo dkk., 2008). Dengan menyebut sejumlah tempat di Jakarta, Bandung, dan Surabaya, yang menjadi sentra-sentra stiker, tim penyusun buku ini juga melakukan investigasi ke sebuah pabrik stiker tertua, AMP Production yang ternyata berada di perdesaan.

Penelusuran tim penyusun ke pabrik AMP Production, di Desa Pakisaji, Kab. Malang, Jawa Timur, membuat buku ini lebih banyak menampilkan sejumlah informasi, tentang bagaimana stiker diproduksi serta dari mana ide-ide itu muncul. Buku ini juga menyiratkan semacam pemikiran tentang hubungan antara stiker dan imajinasi kota. (Moetidjo dkk., 2008: 29).

Tak ada keterangan yang jelas, kapan stiker mulai muncul di Indonesia. Tetapi mungkin bisa diingat bagaimana di pertengahan tahun 1970-an, telah muncul stiker master kungfu, seperti Bruce Lee dalam posisi sedang menendang yang laku keras. Sejak 
tahun 1980-an, stiker berkembang dengan citra yang mengingatkan kita pada bayi gemuk, bertuliskan No Problem, Iwan Fals, Rambo hingga penyebutan yang dicomot dari berbagai dunia hiburan. Stiker berupa teks ketika itu juga telah muncul, namun lebih banyak beredar dan ditempelkan dengan semangat yang sangat konvensional, misalnya, Bebas Tapi Sopan atau Anda Sopan Kami Segan. Sedangkan di ruang publik seperti bis kota atau angkot, juga muncul stiker-stiker teks seperti Yang Cakep Duduk Dekat Supir atau Sekarang Bayar Besok Gratis.

Berbagai perubahan saat ini meluruhkan stiker-stiker sopan, yang muncul pada periode sebelumnya. Pencitraan santun menjadi sinisme, ledekan, hingga pelesetan. Kreasi artistik tak lagi hanya menjadi cerminan kenyataan. Namun kenyataan bisa menjadi cerminan dari kreasi artistik yang ada (Moetidjo dkk., 2008:35). Stiker dan berbagai teksnya yang mudah kita temukan hari ini di berbagai sepeda motor menjadi representasi dari kenyataan bagaimana kota itu diimajinasikan. Namun lebih dari itu, seperti disebut Ayu Utami, stiker telah menjadi bahasa ungkapan paling polos di ruang publik.

Kerangka Pikir Penelitian

Kerangka pikir dalam penelitian ini mengikuti ide analisis Norman Fairclough (1995:57-62) dalam konsep analisis CDA, sebagaimana tergambar pada diagram di bawah ini.

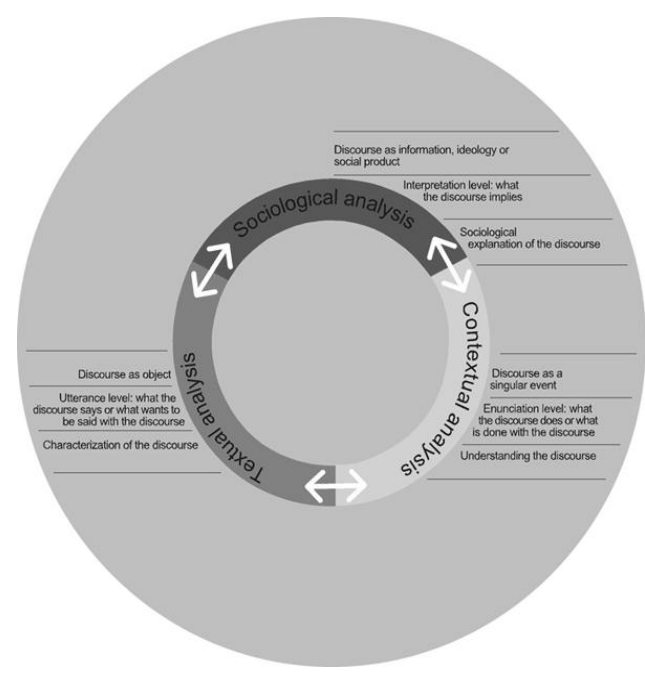

1) Analisis Teks (Mikrostruktur Analisis) 
Pada tahap ini, teks pada stiker sepeda motor dianalisis secara linguistik, dengan melihat kosakata, tata bahasa, semantik, tata kalimat, unsur koherensi dan kohesivitas, serta pola bagaimana kata atau kalimat digabung sehingga membentuk pengertian. Semua elemen yang dianalisis tersebut dipakai untuk melihat tiga masalah berikut; Pertama, ideasional, yang merujuk pada representasi tertentu yang ingin ditampilkan dalam teks, yang umunya membawa muatan ideologis tertentu. Analisis ini pada dasarnya ingin menyikapi sesuatu yang ditampilkan dalam teks, yang bisa jadi membawa muatan ideologis tertentu. Kedua, relasi, merujuk pada analisis bagaimana konstruksi hubungan di antara penulis dengan pembaca, seperti apa teks disampaikan: secara informal atau formal, terbuka atau tertutup. Ketiga, identitas, merujuk pada konstruksi tertentu dari identitas penulis dan pembaca, serta bagaimana wujud personal dan identitas ini hendak ditampilkan.

\section{2) Analisis Praktik Kewacanaan (Analisis Mesostruktur)}

Dimensi ini berhubungan dengan berhubungan dengan "proses produksi, konsumsi dan distribusi" sebuahteks. Setiap tipe tulisan pada stiker sepeda motor pada dasarnya dihasilkan lewat proses produksi teks yang berbeda, seperti bagaimana pola kerja, bagan kerja, dan rutinitas dalam menghasilkan teks. Proses produksi yang satu mungkin sekali mempunyai pola kerja dan kebiasaan yang berbeda dibandingkan dengan yang lain. Proses konsumsi teks bisa jadi juga berbeda dalam konteks sosial yang berbeda pula, seperti secara personal atau secara kolektif. Sementara itu, prosesdistribusi tekstergantung pada pola dan jenis teks dan bagaimana sifat institusi yang melekat dalam teks tersebut.Dengan demikian, hubungan antara teks dan praktik sosial selalu diperantarai praktik kewacanaan. Oleh sebab itu hanya melalui praktik kewacanaan saja (tempat orang menggunakan bahasa untuk menghasilkan dan mengonsumsi teks), teks bisa membentuk dan dibentuk oleh praktik sosial.

3) Analisis Praktik Sosial (Analisis Makrostruktur) 
Analisis praktik sosial adalah dimensi yang berhubungan dengan konteks di luar teks, seperti seperti konteks situasi, lokasi, atau posisi penulis/pembicara dan media dalam hubungannya dengan masyarakat atau budaya dan politik tertentu, serta fenomena sosial yang mengilhami penciptaan teks. 


\section{METODE PENELITIAN}

Metode

Kajian ini menggunakan metode kualitatif dengan pendekatan analisis wacana kritis Critical Discourse Analysis. Pendekatan yang dipergunakan dalam penelitian ini adalah paradigma kritis yang menaruh perhatian terhadap pembongkaran aspek-aspek tersembunyi di balik sebuah kenyataan yang tampak (virtual reality) tertera pada tulisan stiker sepeda motor.

Objek penelitian mencakup: 1) tata bahasa dan unsur linguistik dalam stiker; 2) pola hubungan antar partisipan yang terjalin melalui ungkapan dalam stiker; dan 3) fenomena sosial budaya tergambar pada stiker. Data yang dipakai terdiri dari 70 stiker sepda motor yang diyakini ada kaitan satu dengan lainnya. Data diperoleh dari beberapa sumber: 1) dari stiker yang ditempelkan pada sepeda motor 2) dari beberapa tempat penjualan stiker sepeda motor di Kota Surabaya, sebagai salah satu sentra penjualan stiker di Indonesia (Moetidjo dkk, 2008); 3) dari internet.

Sesuai dengan ketiga sumber data, pengumpulan data pada kajian ini dilakukan dengan teknik observasi. Stiker dikumpulkan dengan mencatat kalimat tertempel pada sepeda motor, mengunjungi penjual stiker, serta mengumpulkannya lewat internet.

Penelitan ini menggunakan teknik analisis wacana model Norman Fairclough, yang didasarkan pada konsep menghubungkan level mikrostruktur dengan konteks masyarakat yang makro.

1) Analisis Mikrostruktur (Proses produksi)

2) Analisis Mesostruktur (Proses interpretasi

3) Analisis Makrostruktur (Proses wacana)

Untuk menemukan "realitas" di balik teks kita memerlukan penelusuran atas konteks produksi teks, konsumsi teks, dan aspek sosial budaya yang mempengaruhi pembuatan teks. Cara ini juga akan digunakan peneliti dalam proses analisis data (Fairclough, 1995:57-62)

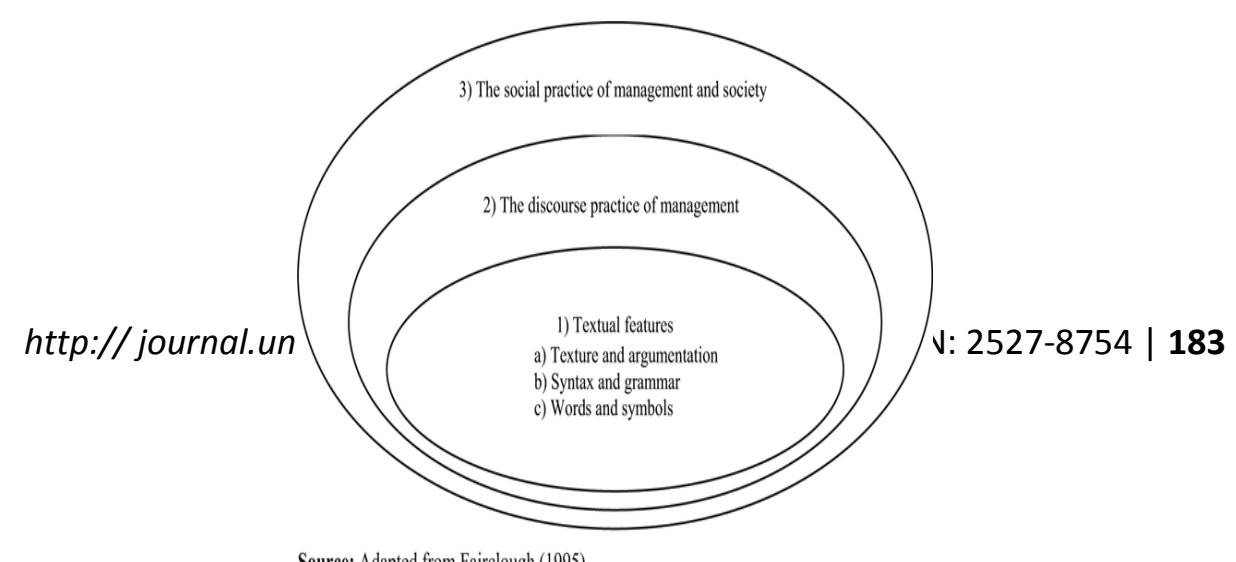


Dalam penelitian ini, penulis menggunakan Triangulasi Periset, yakni triangulasi menggunakan lebih dari satu periset dalam mengadakan observasi atau wawancara karena masing-masing periset mempunyai gaya, sikap dan persepsi yang berbeda dalam mengamati fenomena. Pengamatan dan wawancara dengan menggunakan dua periset.

Stiker-stiker telah dikelompokkan ke dalam beberapa tipe untuk memudahkan proses analisis. Pada bab ini, analisis mikro dipaparkan terlebih dahulu, menyusul analisis pada level meso dan makro.

\section{PEMBAHASAN}

Tata Bahasa dan Unsur Linguistik pada Stiker Sepeda Motor: Level Mikro

Analisis pada level ini mencakup analisis pola struktur bahasa dan analisis unsurunsur kebahasaan yang termuat pada stiker yang pola bahasanya digunakan bersifat informal, singkat, langsung, dan kaya makna dengan penggunaan beberapa majas yang menggelitik.

Sebagai contoh, pada stiker Hari gini pake matic skalian aja pake lipstick, kalimat tersebut merupakan klausa. Hari gini sebagai keterangan (Ket), pake sebagai predikat $(\mathrm{P})$, matic sebagai objek $(\mathrm{O})$, sekalian aja pake sebagai predikat (P), dan lipstick sebagai objek (O). Klausa tersebut merupakan klausa tak lengkap, karena hanya tersusun oleh Ket-P-O-P-O. Apabila dilihat dari segi variasi bahasanya, maka dapat ditelaah dari dua segi yakni dari segi penutur dan segi keformalan. Variasi bahasa dari segi penutur, data tersebut memiliki dua variasi, yaitu idiolek dan sosiolek. Idiolek karena melihat dari warna suara, pilihan kata, gaya bahasa, dan susunan kalimat. Sosiolek karena dilihat dari variasi bahasa berdasarkan jenis kelamin, isinya ditujukan untuk seorang pria.Sementara itu, variasi bahasa dari segi keformalan termasuk ragam akrab. Ragam akrab karena kalimat tersebut biasa digunakan dengan teman akrab dan bahasanya juga tidak jelas. Maksud dan tujuan petuturan stiker adalah menunjukkan sebuah sindiran.

Pola bahasa yang informal lainnya tergambar pada pola struktur kalimat yang tidak lengkap. Contohnya: Anda tepat di belakang orang ganteng. Kalimat ini tidak 184 | E-ISSN: 2527-8754 http:// journal.unesa.ac.id/index.php/Paramasastra 
memililiki predikat yang sesuai. Ada satu kata yang hilang. Apabila dibenarkan, kalimat tersebut seharusnya menjadi: Anda (berada/berdiri/duduk) tepat di belakang orang ganteng.

Pola bahasa tidak baku juga tergambar dengan penggunaan slang atau prokem tertentu yang sangat tidak lazim digunakan dalam ragam bahasa tulis, misalanya dalam tulisan stiker: (1) delete mantan download gebetan, (2) gak tajir gak usah naksir, (3) Kredit loe aja kali gue engga. Bahasa slang dirumuskan sebagai ragam bahasa yang tidak resmi dipakai oleh kaum remaja atau kelompok sosial tertentu untuk komunikasi intern sebagai usaha supaya orang di luar kelompoknya tidak mengerti; berupa kosa kata yang serba baru dan berubah-ubah. Slang adalah variasi ujaran yang bercirikan kosa kata yang baru ditemukan dan cepat berubah; dipakai oleh kaum muda atau kelompok sosial dan profesional untuk komunikasi ke dalam. Slang digunakan sebagai bahasa pergaulan. Kosakata slang dapat berupa pemendekan kata, penggunaan kata alam diberi arti baru atau kosakata yang serba baru dan berubah-ubah. Disamping itu slang juga dapat berupa pembalikan tata bunyi, kosakata yang lazim diapakai di masyarakat menjadi aneh, lucu, bahkan ada yang berbeda makna sebenarnya.

Selain itu, kosakata bahasa prokem di Indonesia diambil dari kosa kata bahasa yang hidup di lingkungan kelompok remaja tertentu. Pembentukan kata dan maknanya sangat beragam dan bergantung pada kreativitas pemakainya. Bahasa prokem berfungsi sebagai ekspresi rasa kebersamaan para pemakainya.

Kehadiran bahasa prokem itu dapat dianggap wajar karena sesuai dengan tuntutan perkembangan nurani anak usia remaja. Masa hidupnya terbatas sesuai dengan perkembangan usia remaja. Selain itu, pemakainnya pun terbatas pula di kalangan remaja kelompok usia tertentu dan bersifat tidak resmi. Jika berada di luar lingkungan kelompoknya, bahasa yang digunakannya beralih ke bahasa lain yang berlaku secara umum di lingkungan masyarakat tempat mereka berada.

Sebagian besar bahasa yang digunakan pada stiker juga mengunakan majas perbandingan (asosiasi) dengan permainan unsur homomim kata yang kreatif.

Contoh Hari gini gak pake gigi ompong dong.

2. Hari ini gak ada gigi udah kaya engkong gua. 
Dari dua contoh di atas, kata yang memiliki unsur yang homonim adalah kata gigi. Kata tersebut memiliki dua arti yang sangat berbeda ketika dilekatkan pada konteksnya masing-masing. Kata gigi pada kalimat: Ahmad mengendarai sepeda motor gigi berbeda dengan kata yang sama pada kalimat: Kakek sudah tidak mempunyai gigi lagi. Arti pertama kata gigi mengacu kepada jenis kendaraan (sepeda motor) yang memiliki perseneling, sedangkan arti berikutnya mengarah kepada salah satu organ tubuh manusia yang memiliki fungsi utama mengunyah makanan.

Fenomenena bahasa yang unik ini kemudian digunakan oleh pembuat stiker dengan mengasosiasikan pengguna sepeda motor bukan gigi (sepeda motor matik) dengan kata engkong dan ompong. Asosiasi ini sebenarnya melemahkan gambaran para pengguna motor matik karena mereka dibandingkan dengan orang yang sudah tua (engkong) dan lemah bagaikan tidak mempunyai gigi lagi.

Motor matik yang paling banyak digunakan saat ini karena kemudahan penggunaanya dan adanya ruang di bagian depan untuk tempat barang, belum lagi ditambah bagasi yang ada dibawah sadel motor pada umumnya membuat motor jenis ini menjadi pilihan primadona. Motor jenis matik awalnya hanya banyak digunakan oleh kaum wanita saja. Namun saat ini jenis motor ini banyak digunakan oleh kaum pria juga. Seiring gencarnya promosi yang digaungkan oleh setiap dealer motor dan bentuknya semakin variatif, motor ini telah menjadi pilihan alternatif para pria. Kondisi ini berpengaruh juga pada pemilihan bahasa yang digunakan oleh para pembuat stiker sepeda motor, sebagaimana tergambar pada tulisan berikut:

AKU LELAKI LEBIH BAIK DIBILANG JELEK DARIPADA CANTIK MAKANYA AKU PILIH NAIK OJEK DARIPADA NAIK MATIK

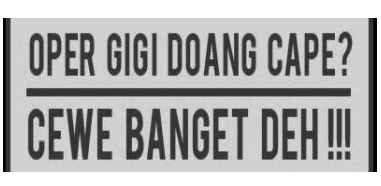

Bentuk homonim yang juga dimanfaat oleh para pembuat stiker adalah homonim pada kata bebek. Kata ini memiliki dua arti yang berbeda pada dua kalimat berikut ini:

\section{Seekor bebek sedang berenang di kolam.}

\section{Andi memiliki sepeda motor bebek.}


Arti kata bebek dalam kalimat pertama adalah jenis unggas peliharaan yang pandai berenang, sedangkan kata bebek pada kalimat kedua mengarah pada salah satu jenis sepeda motor tanpa kopling. Bentuk homonim pada kata ini kemudian dijadikan bahan tulisan stuker dengan menggunakan gaya bahasa pertentangan: Punya motor bebek tapi kok ketemu banjr takut. Bebek kan bisa berenang.

Kajian unsur bahasa yang juga menarik dalam level analisis tingkat mikro ini adalah kajian intertektualitas yang berarti bahwa beberapa informasi dalam satu teks yang terkait teks-teks dari sumber lain (Fairclough, 1992, 1995 dan 2003). Intertekstualitas merupakan salah satu gagasan penting dari Fairclough yang dikembangkan dari pemikiran Julia Kristeva dan Michael Bakhtin. Ini adalah sebuah istilah yang menerangkan bahwa teks dan ungkapan dibentuk oleh teks yang datang sebelumnya, saling menanggapi dan salah satu bagian dari teks tersebut mengantisipasi lainnya. Setiap ungkapan dihubungkan dengan rantai dari komunikasi. Semua pernyataan/ ungkapan didasarkan oleh ungkapan yang lain, baik eksplisit mapun implisit. Menurut Bakhtin, wacana bersifat dialogis, seorang penulis teks pada dasarnya tidak berbicara dengan dirinya sendiri dan menyuarakan dirinya sendiri. Ia berhadapan dengan suara lain, teks lain.

Dengan kata lain, intertekstualitas berkenaan dengan faktor-faktor yang membuat pelaksanaan satu teks bergantung pada pengetahuan dari satu atau lebih teks yang dijumpai sebelumnya. Menurut prinsip interteksualitas, setiap teks dibaca dan harus dibaca dengan latar belakang teks-teks lain. Hal itu menunjukkan bahwa akan senantiasa ada keterkaitan antara teks yang satu dengan teks yang lain.

Unsur interteksualitas dalam stiker sepeda motor misalnya dapat terpantau jelas dalam 'peperangan' antara pengguna motor gigi dan pengguna motor matik, sebagaimana terlihat pada keterkaitan antara dua teks berikut ini:

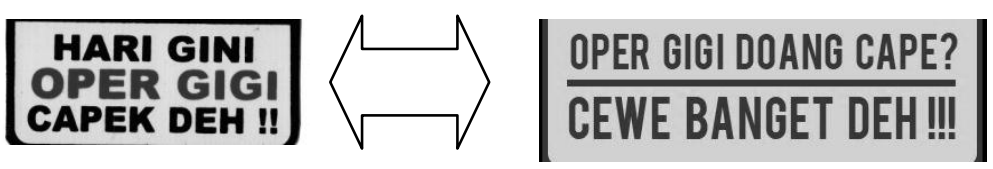

Stiker Oper gigi doang cape? Cewe banget deh depengaruhi oleh teks stiker yang 
muncul sebelumya Hari gini oper gigi. Capek deh. Bentuk intertektualis yang tertuang dalam tulisan stiker ini bersifat pernyataan dan tanggapan atas pernyataan. Hal ini menunjukkan adanya keterkaitan antarteks, satu teks dibuat sebagai tangggapan atas teks sebelumnya atau diilhami teks yang mendahuluinya.

Berdasarkan beberapa uraian di atas, beberapa unsur bahasa dalam stiker sepeda motor dapat diringkas ke dalam poin-poin berikut ini:

1. Pola bahasa yang digunakan adalah pola ragam akrab/ragam tidak baku dengan, menggunakan kalimat singkat dengan struktur kalimat yang tidak lengkap.

2. Terdapat penggunaan prokem atau slang yang mengacu pada unsur sosiolek ciri pengguna bahasa anak muda,

3. Penggunaaan bentuk homonim untuk menciptakan gaya bahasa perbandingan dan pertentangan.

4. Terdapat stiker yang mengandalkan pola intertekstualitas pada bahasa yang digunakan dalam stiker.

Hubungan Antarpartisipan pada Stiker Sepeda Motor: Level Meso

Analisis pada level ini terfokus pada dua aspek yaitu produksi teks dan konsumsi teks yang dikaitkan dengan lokasi, sikap dan tindakan tokoh yang tergabung dalam wacana. Pada analisis level ini, para peneliti membuat pola hubungan antara tokoh atau partisipan yang terlibat dalam jenis-jenis stiker yang telah dikelompokkan. Ditemukan tiga pola hubungan yang kuat antarpartisipan yang terlibat dalam produksi dan konsumsi stiker yaitu, pola hubungan antarpengguna sepeda motor, pola hubungan antarkelas sosial, dan pola hubungan antar gender.

\section{Pola Hubungan Antarpengguna Sepeda Motor}

Pergeseran minat ini dari sepeda motor gigi ke sepeda motor matik tentu saja membawa semacam 'peperangan' antara pengguna sepeda motor gigi dan pengguna sepeda motor baru matic. Para pengguna sepeda motor berperseneling yang enggan beralih menggunakan sepeda motor matic kemudian mengilhami produksi teks stiker yang seolah-olah mengolok para pengguna sepeda motor matic. Sebaliknya, para pengguna sepeda motor matic tidak tinggal diam. Mereka menempeli sepeda motor mereka dengan stiker balasan yang menunjukkan adanya 'perang' antarpengguna. 
Ketika para pengguna sepeda motor bergigi menampilkan stiker: Aku lelaki lebih baik dibilang jelek daripada cantik. Makanya aku pilih naik ojek daripada naik matik,para pengguna sepeda motor matic menampilkan stiker tandingan: Cowok naik matic ceweknya pasti cantik. Ketika para pengguna sepeda motor matic menampilkan stiker Hari gini oper gigi capek deh, para pengguna sepeda motor bergigi menampilkan stiker: Oper gigi doang cape? Cewek banget deh!!! Pola bahasa yang digunakan kadang bernada sindiran dan menyudutkan pihak lawan. Dengan mengandalkan gambaran awal motor matic yang diperuntukkan buat kaum hawa, para pria pengguna motor matic menjadi bulan-bulanan dalam stiker; misalnya: Cowok pake matic sekalian aja bibirnya pake lipstic.

Persaingan ini melahirkan pergeseran 'mitos' yang pada awalnya diciptakan oleh produsen motor matic untuk meraih pangsa pasar wanita. Mitos tersebut misalnya:

1) Motor manual akan menghasilkan kesan macho dan tomboy ketika dipakai seorang lelaki. Sebaliknya motor matic akan menghasilkan kesan feminin.

2) Untuk saat ini, motor manual pilihan warnanya lebih sedikit daripada motor matic, untuk kategori warna-warna pastel dan putih.

3) Motor manual membutuhkan kerja dan energi ekstra ketika mengendalikannya (tangan dan kaki sama sibuknya) dibandingkan motor matic (kaki tinggal diam manis).

4) Motor matic lebih memudahkan wanita yang menggunakan rok dibandingkan motor manual.

5) Motor matic mempunyai bagasi terbuka bagian depan yang luas sehingga sangat sesuai dengan kebutuhan ibu-ibu yang (suka) shopping dan membawa banyak bawaan.

\section{Pola Hubungan Antarkelas Sosial}

Entah apakah anggapan tersebut bisa dibuktikan atau tidak, stiker sepeda motor kredit, lo aja kali gua engga hendak menunjukkan bahwa penggunanya tidak mau disamakan dengan mereka yang membeli (sepeda motor) secara kredit. Ungkapan senada dengan bahasa yang berbeda juga tampak dalam stiker: motor kredit dilarang nyalip atau yang belum lunas dilarang nyalip. Produksi tulisan-tulisan pada stiker di atas secara implisit menerangkan bahwa terdapat perbedaan kelas sosial antara para pembeli sepeda 
motor, mereka yang membeli tunai lebih tinggi dan lebih bangga daripada mereka yang membeli secara kredit. Uniknya, tanggapan pengguna sepeda motor kreditan tidaklah seekstrim tanggapan dua tipe sepada motor yang dibahas pada poin sebelumnya. Stiker: jangan dicuri masih kreditan malah menimbulkan efek lucu bagi para pembacanya.

Pola Hubungan Antargender: Gender Stereotypes

Stereotip gender umumnya populer dianggap memiliki konotasi negatif pada over generalisasi yang dibuat. Pertama, dengan meneliti ucapan-ucapan tokoh sentral dalam stiker, dapat diungkapkan bahwa laki-laki sering digambarkan sebagai superordinate (atasan) dan perempuan pada posisi subordinate (bawahan). Dalam stiker, laki-laki diberi peran gender penghakiman; mereka memberikan kesan 'macho' dan mereka menawarkan informasi jantan dan feminim melalui jenis sepeda motor yang mereka kendarai. Berikut adalah contohnya.

\section{pria sejati \\ oper gigi \\ pakai \\ tancan kiri}

AKU LELAKI
LEBIH BAIK DIBILANG JELEK
DARIPADA CANTIK
MAKANYA AKU
PILIPANAIK OSEK
DARIPADA NAIK MATIK

Sebaliknya, wanita digambarkan sebagai bawahan. Oleh karena itu, akan menjadi 'tabu' untuk laki-laki jika mereka mengikuti tindakan yang biasa dilakukan perempuan.

Contoh

\section{$\left|\frac{\text { OPER GIG DOANG CAPE? }}{\text { CEWE BANGET DEH!!!! }}\right|$}

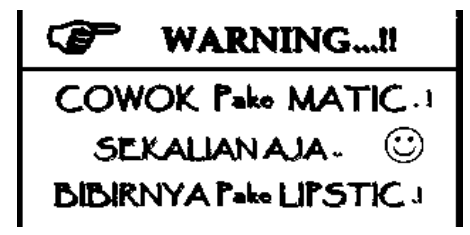

Dalam pengaturan tersebut, perempuan digambarkan kurang berpengetahuan dibandingkan laki-laki, dan pada gambaran yang lebih lanjut tersirat bahwa perempuan seringkali lebih lemah dari laki-laki, tidak dapat 190 | E-ISSN: 2527-8754 http:// journal.unesa.ac.id/index.php/Paramasastra 
melakukan hal-hal yang kompleks sendiri, dan perlu laki-laki untuk menyelesaikan peran mereka .

Kedua, dengan meneliti ucapan-ucapan tokoh sentral dan elemen visual dari stiker, ditemukan bahwa pria digambarkan dengan fokus pada prestasi mereka, dan perempuan digambarkan dengan fokus pada atribut fisik mereka. Secara implisit, hal ini menampilkan ide-ide konvensional tentang ruang gerak dan peran laki-laki dan perempuan. Dalam stiker, perempuan digambarkan 'sibuk' dengan bentuk tubuh, berat badan, dan penampilan fisik. Dengan demikian, para pembuat stiker memperkuat hubungan yang berlaku antara perempuan dan atribut fisik melalui wacana stereotip normatif.

Ketiga, dengan meneliti peran peserta dalam analisis tingkat meso ini, ditemukan bahwa masih ada masalah seperti pembagian peran di ruang publik dan domestik antara laki-laki dan perempuan. Pria mengurus ruang publik, sementara wanita mengurus lingkungan domestik (laki - laki mencari nafkah, perempuan menjaga rumah). Contoh eksplisit dapat dilihat pada stiker di bawah ini.

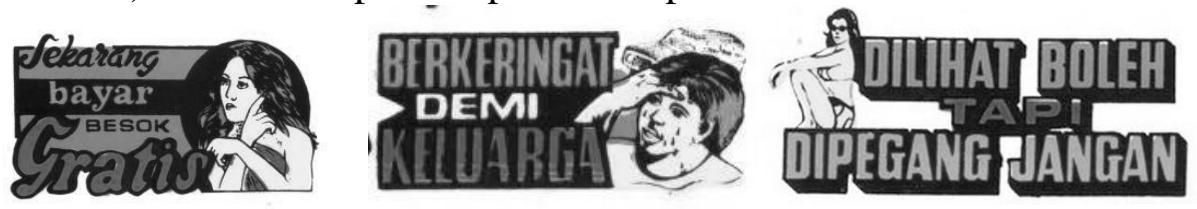

Dalam hal ini, situasi gender Indonesia masih berhubungan kuat dengan isu kesetaraan gender di bidang publik dan domestik . Karena stagnasi dan tidak ada kemajuan peran progresif gender dan norma-norma di wilayah domestik, partisipasi perempuan di ranah publik tidak optimal karena perempuan masih membawa beban ganda dan ditekan oleh masyarakat.

\section{Refleksi Fenomena Sosial dari Stiker Sepeda Motor: Level Makro}

Tiga refleksi utama adalah tentang bagaimana kelas sosial tergambar pada bahasa stiker, tentang kebijakan sosio-politis, bidang gender, serta tentang femonema bahasa gaul di Indonesia.

Kelas Sosial dalam Stiker Sepeda Motor 
Teks adalah hasil lingkungannya, hasil pemilihan makna yang terus-menerus, yang dapat digambarkan sebagai jaringan yang membentuk suatu sistem kebahasaan (Halliday dan Hassan, 1992: 15). Konteks dipadatkan ke dalam sebuah teks melalui cara yang sangat sistematis di antara lingkungan sosial dengan organisasi bahasa. Wacana ditetapkan dan juga dikondisikan secara sosial—aspek-aspek sosial tersebut meliputi situasi, objek pengetahuan dan identitas sosial, serta hubungan antara orang-orang dan berbagai kelompok orang (Wodak, 1996:15 dalam Titscher, 2009: 44). Wacana selanjutnya berfungsi untuk mempertahankan dan mengubah keadaan sosial masyarakat tempat wacana tersebut hidup. Selain itu, wacana bisa juga dianalisis untuk melihat gejala-gejala sosial yang terdapat dalam sebuah masyarakat.

Individu, institusi, dan agen lainnya mencoba membedakan dirinya dari yang lain dan mendapatkan modal yang berguna atau berharga di arena tersebut (Harker et al., 2005:xi). Praktik identitas kelas dalam stiker ini telah menjadi praktik yang sarat ideologi. Ideologi tidak berhubungan dengan kelas tertentu, tetapi dengan ciri fundamental "pembagian sosial"e (Thompson, 2007: 47). Terdapat pembagian antara yang mendominasi dan yang didominasi, kelas atas dan kelas rendah, selera tinggi dan selera rendah. Marx mengatakan bahwa suatu masyarakat tidak dapat eksis tanpa menempatkan representasi kelompok-nya. Representasi kelompok dalam konteks relasi sosial yang terbatas dan berubah menyiratkan proyeksi suatu "imajinasi komunitase melalui perbedaan-perbedaan nyata yang digambarkan sebagai bersifat "alamiec. Hal-hal yang partikular disembunyikan dalam hal yang universal, hal yang bersifat historis disamarkan dalam temporalitas pokok persoalan (Thompson, 2007: 47). Imajinasi sosial diekspresikan melalui pembentukan dunia makna. Melalui makna tersebut—simbol dan mitos tempat masyarakat menghadirkan masa kini dan masa lalunya - suatu masyarakat dibekali identitas dan dibedakan dari masyarakat yang lain. Melalui imajinasi sosial ini, kelompok masyarakat mengidentifikasi-kan dirinya dari yang lain

Penggunaan stiker sepeda motor ini telah menjadi semacam konkretisasi modal ekonomi dan budaya seseorang. Masyarakat pengguna stiker sepeda motor menyuguhkan pemandangan gengsi sebuah kelas sosial ke masyarakat dari kelas lainnya. Stiker sepeda motor kini telah bergeser fungsi. Jika pada awalnya ia hanya berfungsi sebagai hiasan dan kini berfungsi menjadi penunjuk identitas kelas. 
Fenomena Kesetaraan Gender di Indonesia

Indonesia telah berperan aktif dalam berbagai konvensi internasional yang menyuarakan kesetaraan gender dan pemberdayaan perempuan. Konvensi-konvensi tersebut antara lain CEDAW 1979 (Convention on the Elimination of All Forms of Discrimination AgainstWomen), ICPD 1994 (International Conference on Population and Development), Plat form of Action, dan MDGs (Millennium Development Goals). Selain itu, bulan Agustus 2007, PBB memberikan penghormatan kepada Indonesia untuk proliferasi UU No 21/2007 tentang Perdagangan Manusia, UU No 12/2006 tentang Kewarganegaraan (anak dengan ibu WNI dan ayah WNA memiliki hak terhadap dual kewarganegaraan sampai berusa 18 tahun), dan UU No 23/2004 tentang Kekerasan Dalam Rumah Tangga (Wardhani, 2007).

Dalam perspektif sosial, perempuan Indonesia masih diharapkan mengambil peran perawatan rumah tangga dan bertanggung jawab dalam ranah domestik, memelihara anak-anak, masak, dan berlaku baik di 'tempat tidur'.

Dalam rumah tangga Indonesia, para orang tua sering tidak menyadari bahwa mereka memberlakukan stereotip peran gender tradisional dan normanorma gender kepada anak-anak mereka. Gadis diajarkan untuk menjadi "nrimo", yaitu, untuk menerima apapun yang mereka dapatkan (Utomo, 2005: 70). Sejak awal anak perempuan dilatih untuk dekat dan bermain di sekitar rumah; sementara anak laki-laki diharapkan dapat menjelajahi dunia luar rumah ketika bermain dengan kawan-kawan mereka.

Konten media seperti pada stiker sepeda motor bisa menyebabkan orang membuat interpretasi, karena mereka berpegang pada stereotip yang mereka kenal. Representasi stereotip tersebut akan mendorong individu untuk menginternalisasi citra konstruksi sosial tentang feminitas dan maskulinitas yang disajikan dalam konten media.

Fenomena Bahasa Gaul di Indonesia

Penggunaan bahasa gaul dalam kehidupan sehari - hari ini mempunyai pengaruh negatif bagi kelangsungan bahasa Indonesia. Pengaruh tersebut antara lain sebagai berikut. 
1) Masyarakat Indonesia susah mengenal ragam bahasa baku.

2) Masyarakat Indonesia tidak memakai lagi Ejaan Yang Disempurnakan (EYD).

3) Dulu anak-anak kecil bisa menggunakan bahasa Indonesia yang baik dan benar, tapi sekarang anak kecil lebih menggunakan bahasa gaul.

4) Penyalahgunaan arti bahasa Indonesia yang terdapat pada KBBI. Misalnya saja kata "lebai" dalam bahasa gaul artinya berlebihan. Namun jika dilihat dari KBBI, jika berfungsi sebagai kata benda atau nomina, "lebai" mempunyai arti sebagai pegawai mesjid.

5) Penulisan bahasa indonesia menjadi tidak benar.

\section{SIMPULAN}

Tiga kesimpulan utama dapat dibuat berdasarkan pertanyaan penelititian dalam studi ini:

1) Mikro CDA: pola bahasa yang digunakan dalam tulisan stiker sepeda motor adalah pola ragam akrab/ragam tidak baku dengan menggunakan kalimat singkat dengan struktur kalimat yang tidak lengkap. Selain itu, terdapat penggunaan prokem atau slang yang mengacu pada unsur sosiolek ciri pengguna bahasa anak muda, penggunaaan bentuk hominim untuk menciptakan gaya bahasa perbandingan dan pertentangan, juga terdapat stiker yang mengandalkan pola intertekstualitas pada bahasa yang digunakan dalam stiker.

2) Meso CDA: berdasarkan pengelompokkan tipe stiker, ditemukan tiga pola hubungan yang kuat antarpartisipan yang terlibat dalam produksi dan konsumsi stiker: persaingan antara pengguna sepeda motor berperseneling dan pengguna sepeda motor matic membawa semacam 'peperangan'; budaya konsumtif antarpartisipan yang membeli sepeda motor secara tunai dan secara angsuran; pola hubungan antargender ditandai dengan adanya over- generalisasi tentang karakteristik berdasarkan jenis kelamin, yang lazim disebut stereotip gender.

3) Makro CDA: tiga refleksi utama dalam kajian fenomena sosial pada bagian ini, yakni gambaran kelas sosial pada bahasa stiker, kebijakan sosio-politis bidang gender di Indonesia, serta femonema bahasa gaul yang berpengaruh terhadap penggunaan Bahasa Indonesia yang baik dan benar. 
Penelitian memanfaatkan metode kualitatif dengan menggunakan data tulisan stiker sepeda motor sebagai instrument utama. Desain penelitian yang berbeda dapat digunakan pada penelitian selanjutnya, dengan melibatkan interview atau observasi langsung terhadap para pembuat dan pengguna stiker. Analisis pada level meso dan makro dapat dilakukan lebih rinci dengan melibatkan aspek-aspek lain yang belum tergali dalam penelitian ini.

\section{DAFTAR RUJUKAN}

Brown, G. dan G. Yule. (1983). Discourse Analysis. Cambridge: CambridgeUniversity Press.

Cook, G. (1994). Discourse and Literature: The Interplay of Form and Mind. Oxford: Oxford University Press.

Coulthard, M. (1985). Introduction to Discourse Analysis. London: Longman.

Dijk, T. A. V. (1985) (ed.) Handbook of Discourse Analysis, vol. 1-4. London:Academic Press.

Georgakopoulou, A. dan Goutsos, D. (1997). Discourse Analysis: AnIntroduction. Edinburgh: Edinburgh University Press.

Fairclough, N. (1989). Language and Power. London: Longman.

Fairclough, N. (1992). Discourse and Social Change. Cambridge: PolityPress.

Fairclough, N. (1995). Media Discourse. New York: Edward Arnold.

Fairclough, N. (1995) Critical Discourse Analysis, London: Longman

Fairclough, N. (2001). Language and Power. 2nd edition. Harlow: Pearson Education Limited.

Fairclough, N. (2003). Analysing Discourse: Textual Analysis for SocialResearch. New York: Routledge.

Fairclough, N. dan R Wodak. (1997) 'Critical discourse analysis'. In T. A. van Dijk (ed.), Discourse Studies: A Multidisciplinary Introduction, Vol. 2. London: Sage.

Halliday, M.A.K. (1978) Language as Social Semiotic. London: Arnold.

Halliday, M. A. K. (1989). Spoken and Written Language. Oxford: OxfordUniversity Press.

Halliday, M.A.K. (1994). "Systemic Theory". In R.E. Asher (ed) Encyclopedia of Language and Linguistics, Vol 8. Pergamon Press. Reprinted in full in Halliday, 
M.A.K. 2003. On Language and Linguistics: Volume 3 in the Collected Works of M.A.K. Halliday. London: Continuum p. 436.

Halliday, M.A.K., Ruqaiya Hasan. 1992. Bahasa, Konteks, dan Teks. Yogyakarta: Gadjah Mada University Press.

Harker et al. (ed.). 2005. (Habitus $x$ modal)+ Ranah= Praktik: Pengantar Paling Komprehensif kepada Pemikiran Pierre Bourdieu. Yogyakarta: Jalasutra.

Moetidjo, Ugeng T, Ardi Yunanto, Ade Darmawan, dan Mirwan Andan. (2008). Stiker Kota. Jakarta: Ruang Rupa

Nunan, D. (1993). Introducing Discourse Analysis. London: Penguin English.

Rose, G. (2001). Visual Methodologies: An Introduction to the Interpretationof Visual Materials. London: Sage Publications Limited.

Schiffrin D. (1994) Approaches to Discourse: Language as SocialInteraction. Cambridge, Mass.: Blackwell.

Surana. (2003). Analisis Wacana Stiker Humor Sebagai Alternatif Komunikasi Publik.

Laporan Penelitian. Lembaga Penelitian Universitas Negeri Surabaya.

Tannen, D. (1993). (ed.) Gender and Conversational Interaction. New York: Oxford University Press.

Titscher, Stefan, et al. 2009. Metode Analisis Teks dan Wacana. Editor Prof. Abdul Syukur Ibrahim. Yogyakarta: Pustaka Pelajar.

Thompson, John B. 2007. Analisis Ideologi: Kritik Wacana Ideologi-Ideologi Dunia. Yogyakarta: IRCiSoD.

Utomo, I.D. 2005. Women's Lives: Fifty Years of Change and Continuity. In 'People, Population and Policy in Indonesia', edited by Terence H. Hull.Jakarta and Singapore: Equinox Publishing (Asia) and Institute of Southeast Asian Studies. p.71-125.Equinox Publishing ISBN979-3780-02-9,ISEASISBN 981-230-296-4.

Wardhani, Lynda. 2007. The Implementation of International Gender-Related Policies in Indonesia: Challenges for Gender Equity, paper presented atthe $\mathrm{PhD}$ Mid TermReview Seminar, Australian Demographic and Socialresearch Institute, Australian National University, Canberra.

Wodak, R. (2001) "What CDA is about" In: Wodak, Ruth \& Meyer, Michael (eds.) (2001) Methods of Critical Discourse Analysis. London: Sage. p5. 